\title{
Work organization, human resource practices and employee retention in Indian call centers
}

(C) The Author(s) 2010

Reprints and permissions: sagepub.co.uk/journalsPermissions.nav DOI: $10.1177 / 10384$ IIII038I623 apj.sagepub.com

\section{Mohan Thite}

Griffith University, Nathan, Queensland, Australia

\section{Bob Russell}

Griffith University, Nathan, Queensland, Australia

\begin{abstract}
The literature on call centers often highlights the centrality of HR in stemming employee attrition but is mainly grounded in the realities of in-house call centers in the western economies. In this empirical study of four large Indian call centers we examine specific aspects of HR practice for their effect on retention in the very different context of Indian labor markets. The relationship between HR practices and the realities of the call-centre labor processes operating within a buoyant labor market that offers plentiful job alternatives are explored. The findings suggest that the contribution of HR to employee retention is a necessary but not sufficient condition for retention in the context of Indian call centers.
\end{abstract}

\section{Keywords}

employee retention, human resource practices, Indian call centers, work organization

Powered by information technologies and the Internet, the business process outsourcing (BPO) of information technology-enabled services (ITeS), including customer contact services, is growing rapidly. BPO/ITeS encompasses a wide range of activity from transactional back-office work to customer contact services and corporate support functions while being conducted from a variety of onshore and offshore locations (Srivastava and Theodore, 2006). India lies at the heart of these recent developments. Within less than a decade it has quickly emerged as 'the services-hub

\section{Corresponding author:}

Dr Mohan Thite, Department of Employment Relations \& Human Resources, Griffith Business School, Griffith University, I70 Kessels Road, Nathan, QId 4III, Australia

Email: M.Thite@griffith.edu.au 
of the world' with over a quarter of the off-shored IT/ITeS market (KPMG, 2004: 12). The sector now consists of over 400 companies that employ an estimated 545000 workers (NASSCOM, 2008). With an annual graduate supply of around 3 million (NASSCOM, 2006a) and more than half the population below the age of 25, India is said to have the largest pool of offshore talent across all offshore destinations. Young, well educated, and fluent in English, India's workforce provides the key input for this model of globalization.

Yet, tempering the strategic advantages and the optimistic forecasts that accompany them (Das, 2002; Friedman, 2005; Sheshabalaya, 2005) are sobering challenges that have appeared alongside the outsourcing phenomenon. According to a global call-center report (Holman et al., 2007) Indian call centers have the highest employee turnover of $40 \%$ against a global average of $20 \%$. High attrition plus rapid employment growth translates into very low levels of employee tenure and indeed $60 \%$ of the Indian call centre workforce is estimated to have less than one year of seniority at work. Other, more recent benchmarking analysis (Wallace, 2009) reports that while India had the second lowest average full-time customer service agent annual salary (US\$3334) just ahead of China, it had the greatest level of call centre agent attrition $(38 \%)$ and lowest average employee tenure (11 months) in the Asia Pacific region. Thus, there appears to be a situation in the Indian ITeS/BPO industry where highly qualified workers entering this services sector nonetheless exit the industry in high numbers after short stints at work.

This paper addresses the human resource (HR) implications of providing customer service from afar with particular reference to Indian customer contact centers and the BPO model. We suggest that the workforce-related comparative advantages in infoservice work that India enjoys are also unique HR challenges that beset the outsourcing industry. High employee turnover has potentially destabilizing effects for the industry with flow-on effects for other aspects of HR, including recruitment and training (Budhwar et al., 2006b), remuneration (Sify, 2006), and finally for productivity and unit costs (Thite and Russell, 2007). Using a survey of employees and interviews with HR and operations managers, this study of retention and attrition at four large Indian BPO providers critically analyzes the role that HR is playing in the very dynamic context of offshore business process outsourcing.

We begin with a review of what is already known about HR in call centers with special reference to Indian BPO. We then outline our methodological strategy and provide a review of the case study organizations that participated in this study along with our measurement constructs. Next, we proceed to examine the determinants of retention and attrition among the BPO workers. The final sections of the paper consider the extent to which these factors are present or absent in the centers that we studied and offer suggestions for further research.

\section{HR practices in Indian call centers}

Generally, it has been found that Indian BPOs exhibit formal, structured and rationalized HRM systems that compare favorably with employment related practices in other sectors of the formal economy (Budhwar et al., 2006a; Budhwar et al., 2006b). HRM assumes a strategic role and several employee involvement and commitment 
work practices have been observed (Raman et al., 2007). Commonly found HR measures include structured recruitment and selection practices, formal, regularly timed performance appraisals and associated compensation systems (performance bonuses), as well as specialized needs-based training (Budhwar et al., 2006a).

More recent research has called attention to the growing interest in other dimensions of HR including supportive team leadership, the provision of recreational and cultural facilities and activities, and various employee 'involvement' programs such as 'town hall meetings', committee involvement and suggestion schemes (Budhwar et al., 2009). Noronha and D'Cruz (2009) draw attention to the importance of employment and occupational 'branding' in the management of BPO workers. Job titles such as 'process executive' and other symbols of global corporate membership inform the construction of self-identities around employment and work. Presumably, such identity regulation reinforces organizational attachment (Alvesson, 2004). Nevertheless, high levels of attrition continue to challenge the BPO model and this has led a number of commentators to search for other remedies including more flexible rosters and the option of part-time work, the use of more highly developed internal labor markets and associated career planning, and better labor market co-operation between rival employers (Bhatnagar, 2007; Budhwar et al., 2009; Raman et al., 2007).

Clearly, some of the current initiatives as well as recommendations for future consideration have been influenced by the discussion of high performance work systems (HPWS) (Appelbaum et al., 2000; Arthur, 1994; Huselid, 1995; Macduffie, 1995) and in particular by the application of this construct to call centers in the West (Batt, 1999, 2000, 2002; Batt and Moynihan, 2002; Hutchinson et al., 2000; Kinnie et al., 2000a, 2000b; Russell, 2008). While there are still some differences as to what is included in the notion of HPWS (Combs et al., 2006), in the domain of call centers, HPWS features are said to consist of team work, relatively skilled work and incentivized remuneration systems (Batt, 2000, 2002). To these initiatives other researchers also include active team building activities (e.g. workplace cultural programs), focused training regimes and employment security (Hutchinson et al., 2000; Kinnie et al., 2000a). Much of the HR literature argues that the adoption of such policies will enhance employee retention and consequently organizational performance. Further reference to this literature is made later in the paper under theoretical constructs and measures.

In this article we are interested in whether such claims as they pertain to retention hold up under the very different context that is presented by India where both labor force demographics and labor market characteristics differ considerably from those prevailing in developed Western economies, (see for example, Arzbacher et al., 2002; Bristow et al., 2000; Richardson et al., 2000; Richardson and Belt, 2001). To date, the relationships between various HR initiatives and employee retention have not been thoroughly tested in the quite different context of BPO. Thus, many of the initial studies on HR and work processes in Indian call centers/BPO assume an exploratory role and are mainly based upon descriptive evidence (Budhwar et al., 2006b; Taylor and Bain, 2005, 2006). The survey research that is available has often focused upon the prevalence of various HR practices in BPO as compared to in-house call-center operations carried out in the West while analyzing the effects of variation on attrition rates (Batt et al., 2006). This recent research has provided much needed breadth; 
however, it is based upon single point of observation, managerial interviews. The issue here is that organizational experience is compressed into one voice (Godard and Delaney, 2000). Presumably, due to the difficulties in gaining access to BPO workforces, employee voices have largely been absent from survey research on BPO, thus lending these studies a possible 'top down' bias. Meanwhile, the few studies that have attempted to tap into employee perceptions of HR in Indian call centers have either relied upon very small samples of customer service representatives (CSRs) (D'Cruz and Noronha, 2006; Shah and Bandi, 2003) or upon small numbers of workers spread across a larger number of organizations (Budhwar et al., 2006b).

The study we report upon was designed to address some of these issues. It elicits the perceptions of employees on the front lines of BPO customer service at four large Indian providers. Our aim is to explore the relationships between HR practices, or more accurately employee perceptions of them, and intentions to remain with or exit the employment relationship.

\section{Methodology}

\section{The case studies and sample}

Conducting social research in India presents some challenges, especially with regard to politically sensitive topics such as outsourcing. Off-shoring customer service often involves the sharing of highly confidential information while BPO providers are loath to commit to anything that could possibly compromise the newly founded trust, which underpins relations with principals. Against this backdrop, we decided to adopt a case study approach to our study which was conducted over two visits to India during 2005. During the first, we made industry contacts and obtained in principle approval for a study of HR challenges in the BPO sector from four large provider organizations. Following these approaches, the authors developed a workforce survey to explore and analyze the issues that had been revealed in the initial interviews. This instrument was designed and agreed upon prior to our return visit back to the same companies in late 2005.

During the second visit, we distributed the surveys to HR managers for administration to employees working in a telephone based customer service role. Although the four participating firms operated in multiple locations, survey administration was conducted on a site-by-site basis. At three of the companies the decision was taken to distribute the surveys at a single location whereas the fourth firm covered two locations. Managers were instructed to restrict the survey administration to employees who spent the majority of their working time providing voice-based customer services, had a minimum of three months job tenure and were in non-supervisory roles. We are confident that this form of administration has not skewed the responses. First, workers completed the survey on their own time and on a voluntary basis. Second, as many employees do not view these as long-term jobs, they have little to be guarded about. Furthermore, our results support these presuppositions. A majority of the respondents indicated that they either planned to exit from employment or, at the very least, were uncertain as to whether they would stay. The reasons given for this reticence (see below) indicate that responses to the survey reflected genuine working experiences and 
frustrations. In other words, the responses do not indicate managerial influence over the results, which clearly are not what management might have ideally wished for. Overall 638 surveys were returned. As our employment data is based at company level (see below) while our survey returns came from individual work sites, it is not possible to estimate accurate response rates. The raw returns included 44 surveys from what we will call BPO1, 160 from BPO2, 257 from BPO3 and 177 from BPO4, which makes this one of the largest surveys of Indian BPO workers yet.

The four organizations covered in this study are indigenous third-party ITeS/BPO providers (i.e. Indian owned and operated MNCs). Employment at the time of our study ranged from 1700 agents (BPO1), to 2600 (BPO2), to 5300 (BPO3) and finally 12500 CSRs (BPO4). The latter three organizations currently rank in the top fifteen indigenous third-party ITeS/BPO providers in India (NASSCOM, 2006b). In each company workers are employed across multiple sites, located in different cities, with the largest provider occupying seven different facilities in five major cities. Each of the companies examined here had numerous overseas clients and business processes with their own key performance indicators (KPIs) assigned to process teams that were spread across the different locations.

In line with the demographic trends of the Indian BPO labor market, $61 \%$ of our respondents were male and an overwhelming $90 \%$ were between the ages of 20 and 30 . Only $28 \%$ had previous experience working in an ITeS environment. Meanwhile, just over two-thirds $(67 \%)$ had an undergraduate university degree, while an additional $23.5 \%$ had attained a graduate degree, taking the total number of university graduates to $90 \%$ of the sample. On average, these employees had put in 13 months of service with the employer they worked for at the time of the survey, while the modal figure was just 12 months.

In addition to the employee survey, we also conducted semi-structured qualitative interviews with managerial staff from each of the four participating BPOs. These interviews entailed the use of two protocols, one for the HR management team and the other for operations management. These sessions sought to elicit more detailed data on recruitment and retention challenges, and HR practices. In total, 15 interviews were held, sometimes with one manager and sometimes with the manager and other members of his/her team. Interview notes were taken at these meetings and observer triangulation by the authors was employed for each session.

Despite individual differences between each of the companies, for the purposes of this article, we are mainly interested in the BPO industry and the common HR challenges that it confronts. Thus, in the following analysis the unit of analysis remains fixed on individual worker-respondents and their perceptions and intentions.

\section{Theoretical constructs and measures}

Our workforce survey questionnaire contains five parts composed of both Likert scale questions and other close-ended questions. Sections on training, job design, HR practice and outcomes are included. As this research is set in a new industry (BPO), our investigation is principally exploratory in nature. The survey was designed as a special purpose instrument for the study of BPO. Composite measures (scales) that are used in the data analysis also manifest this aspect of the research. Although they 
are unique to this study, we would emphasize that they do meet commonly accepted reliability criteria and demonstrate theoretical validity (see below). The use of special purpose survey questions is an appropriate approach for exploring novel social settings such as new workplaces. In such circumstances, it represents a strength in the research design.

Given that the main aim of this paper is to explore the effects of HR practices on employee retention and attrition in Indian BPO, we developed a variety of indicators to measure satisfaction with various aspects of HR. These scales are summarized in the Appendix, but their utilization does call for some comment. The analysis includes indices of work load manageability, job skills, training, monitoring, team functioning, workplace socialization practices and elements of the employee relations climate. These factors are often included under the rubric of high performance HR.

Work load manageability refers to perceptions around required work effort and its reasonableness. Presumably, workloads that are judged to be fair and realistic will promote employee retention, while heavy, pressurized work situations are more likely to induce exit. The work load manageability index is composed of eleven items while several of the variables that constitute this construct are specific to call-center work. Job skill refers to two attributes and one relation (Spenner, 1983). First there are the skill demands of the work, such as its complexity and the amount of autonomy required to conduct it (Cappelli, 1993; Clement and Myles, 1994). Second, there are the skills that the worker brings to the job. Of critical importance is the match/ mismatch between supplied and required skills (Livingstone, 1999; Rose, 1994). There has been considerable debate concerning the level of skills required in callcenter work (Bain et al., 2002; Ellis and Taylor, 2006; Frenkel et al., 1999; Russell, 2006, 2009; Taylor and Bain, 1999) as well as with the comparative skill levels associated with BPO (Batt et al., 2006; D'Cruz and Noronha, 2006; Russell and Thite, 2008; Taylor and Bain, 2005, 2006). The skill index used here attempts to capture both the job requirements and the human capital dimensions of skill. We argue that when workers perceive a good fit between required and supplied skills retention will be enhanced. Where there is a mismatch greater attrition is likely to result.

In addition to the skills workers bring to jobs, employers may also act to create or enhance existing skill levels through training (Houlihan, 2002; Sturdy, 2000). Our concern is with how workers perceive such training. Is it adequate in terms of what the work requires? Does it open up pathways for advancement? The construct that is used in this study considers various aspects of training that are unique to call-center work and to BPO. Again, we hypothesize that workers who consider that the employer is making an investment through training are more likely to remain than those who consider training to be inadequate.

The utilization of work teams is another measure which is thought to provide learning and problem solving opportunities for workers. In BPO work teams are a standard feature of work place organization, aligning with specific clients, processes and metrics. Our theoretical construct examines employee perceptions of differing dimensions of working in teams that have been identified in the literature including the possibilities for empowerment, supportive leadership and the potential for unwanted peer pressure (Baldry et al., 1998; Batt, 2000, 2002; Frenkel et al., 1999; van den Broek, 2002; van den Broek, Callaghan and Thompson, 2004). 
We hypothesize that positive assessments of team functioning will be associated with a greater likelihood of employment retention.

Two other constructs are more specific to info-service work. It is generally acknowledged that the monitoring of work takes on a special significance in callcenters (Fernie and Metcalf, 1998; Bain and Taylor, 2000) and in BPO work in particular (Holman et al., 2007; Taylor and Bain, 2005, 2006). Some researchers find a potential source of grievance in the closely monitored environment of the call center while others suggest that workers are likely to consider close monitoring to be part of the job (Lankshear et al., 2001). Perceptions of workplace monitoring are measured by two items as laid out in the Appendix. ${ }^{1}$

Second, numerous authors have drawn attention to the explicit use of cultural and workplace socialization initiatives in call-center work. Some researchers have theorized cultural programming as a deliberate effort to soften the hard target-driven, monitoring approach that characterizes much info-service work (Houlihan, 2002; Kinnie et al., 2000a; Russell, 2002). The index developed for this analysis measures how workers respond to such interventions. Again, it is worth noting that call-center work seems to be particularly rich in organizational efforts to make work socially enjoyable.

A notion of workplace culture also entails more than conscious cultural programming. Apart from such activities, organizational cultures are manifested by the broader actions of management in regards to employees. Organizational actions in the whole field of employment relations bespeak a culture in the eyes of those who work for the organization. Thus it is also necessary to consider more general perceptions workers have of the organizations that employ them. Broader employee perceptions of the organizations they work for are measured by a two-item employee relations (ER) climate index. ${ }^{2}$ Whether the organization is perceived as being trustworthy and well intended towards its employees is likely to have some bearing on future employee intentions as is satisfaction with specific cultural initiatives.

In addition to the various aspects of HR practice canvassed above, our analysis includes a number of single factors that previous studies claim to influence employee retention. Employment security is included in some theorizations of high performance work systems (Kinnie et al., 2000b; Pfeffer, 1998) and is advanced as a factor that enhances employee organizational attachment. Likewise, incentivized remuneration has been identified as one component of high commitment employment systems in call-center work settings (Batt, 2000, 2002; Kinnie et al. 2000a, 2000b). In this study employee judgments pertaining to job security are measured by the query 'The likelihood of lay off or retrenchment at this call center is high' (reverse coded), while perceptions relating to incentivized remuneration are gauged by the following question: 'Any performance bonuses that I receive at this call center are very important to me'.

Lastly, we wish to consider the effects of the external labor market and employee assessments of it. This variable is measured by the question, 'If I were to lose my job here, it would be relatively easy for me to get as good a job at another call center straight away'. Previous studies on the effects of HR practices on retention and attrition often ignore the state of the labor market or take it as a given. More often than not, this means assuming that HR practices are embedded within the type of labor 
markets that characterize highly developed economies. ${ }^{3}$ As previously suggested, labor markets in India cannot be subsumed under a similar set of assumptions. In this study we are especially interested in examining the effects of HR given the very different labor market conditions that prevail in countries such as India.

\section{Findings}

\section{Analysis of the workforce survey}

For the purpose of examining employee retention we created a dummy variable that has the two attributes 'intending to stay' versus 'quitting/uncertain'. Framing the analysis in this fashion allows us to focus on those factors that contribute to strong employee attachment by distinguishing between these connections and an 'other' category that includes definite quits or weak attachments that may well lead to employment separations. A multivariate analysis of the determinants of a dichotomous outcome calls for the employment of a logistic regression technique, which is presented below.

First though, the bivariate correlations, standardized means and standard deviations for each of the measures introduced in the preceding section are arrayed in Table 1 . Noteworthy are correlations between intentions to stay and perceptions of skill levels as well as satisfaction with the amounts and types of training that are undertaken and work team functioning. Weaker associations prevail between retention and perceptions of work intensity, efforts to enhance workplace socialization and the importance of performance bonuses. Employment security does not have the expected association; a greater perceived likelihood of redundancy is weakly associated with greater retention, while workers who feel more secure are also more likely to canvass their options. Those who consider their labor market prospects to be good with easy job substitution are also less likely to show employment attachment, but the bivariate relationship is weak and is also not statistically significant. Relationships among the different HR variables are also strong, indicating that workers who are satisfied with some aspects of HR practice tend to be positive about others.

Table 2 contains the results of the logistic regression analysis. Two variables stand out in the multivariate analysis of retention. Exerting the strongest effect are workers' perceptions of the labor market they occupy. As is evident from $B$ and the $\operatorname{Exp} B$ this relationship is a negative one. Workers who consider that their current jobs are easily replaceable are significantly less likely to exhibit attachment to their employment in any of the four BPO case studies as signified by the negative coefficient that exists between ease of job replacement and retention.

The other important factor in this analysis is the skill evaluations that workers attach to their jobs. Judging the work to be more skilled and hence a better skill fit significantly increases the probability that employees will remain with the employing organization. When our measure of job skill increases by a unit the odds of the employee remaining with the firm are increased by a factor of 1.19 (Exp B). Interestingly, the other HR measures with the exception of the importance of payment bonuses are inconsequential. This latter variable exerts a comparatively strong effect on retention although it falls just short of an acceptable level of statistical significance. 


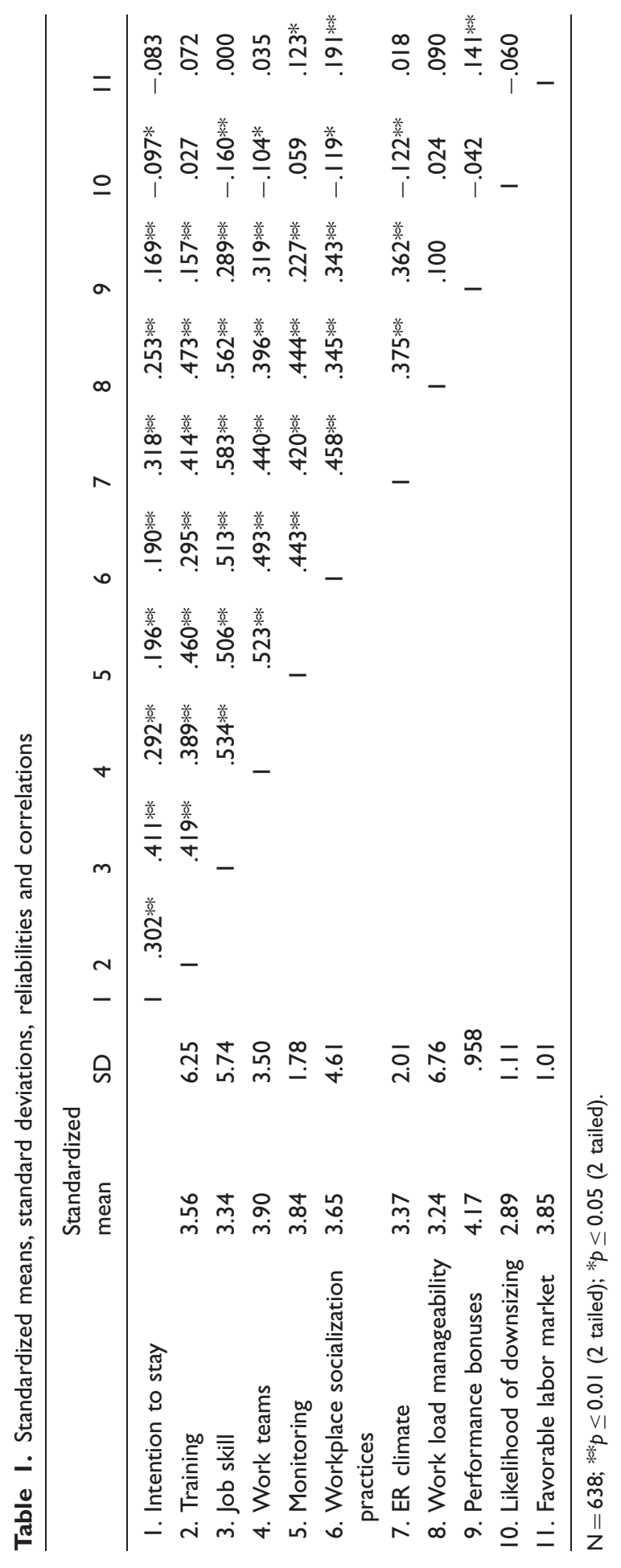


Table 2. Logistic regression analysis predicting employee retention

\begin{tabular}{lclll}
\hline Variables & B & Std error & Exp B & Sig. \\
\hline Job skil & .179 & .059 & 1.19 & .003 \\
Training & .083 & .041 & 1.03 & $\mathrm{~ns}$ \\
Work load manageability & .013 & .040 & 1.01 & $\mathrm{~ns}$ \\
Work teams & -.023 & .076 & .977 & $\mathrm{~ns}$ \\
ER climate & .094 & .134 & 1.09 & $\mathrm{~ns}$ \\
Monitoring & -.273 & .184 & .761 & $\mathrm{~ns}$ \\
Workplace socialization practices & .005 & .058 & 1.00 & $\mathrm{~ns}$ \\
Likelihood of downsizing & -.021 & .202 & .979 & $\mathrm{~ns}$ \\
Favorable labor market & -.481 & .213 & .618 & .024 \\
Performance bonuses & .441 & .256 & 1.55 & .084 \\
\hline
\end{tabular}

Nagelkerke $\mathrm{R}^{2}=0.280$.

Nevertheless, there are valid reasons for supposing that where an important dimension of remuneration occurs in the form of performance-related pay and where workers are satisfied with the administration of such a system, retention will likely be enhanced.

Although perceptions of a highly favorable labor market exert a strong negative pull on the attachment of BPO workers, our analysis suggests that job and employment factors can nullify labor market effects. Where workers consider that their job/ skill match is satisfactory and where they place a high value on incentivized payment schemes that can be realized, the lure of better jobs elsewhere is discounted. Other HR factors appear comparatively inconsequential. For example, efforts to make work more enjoyable through cultural programming register no significant impact upon retaining workers. In other instances such as satisfaction with training and team working, it may be that it is only to the extent that such practices promote skill enhancement that they are valued. In any event, the analysis suggests that it is towards job skill fit and incentivized payment schemes in the context of Indian labor markets that people managers will need to turn their attention. As we suggest in the next section this poses some critical challenges for HR in Indian BPO.

\section{Analysis of the managerial interviews}

Our qualitative interviews with the HR and Operational managers of the four case study firms shed further light on the challenges of retention that currently confront the ITeS/BPO industry in India. Attrition was identified as the chief HR issue at three of the research sites, where if anything, the employee surveys may under-estimate real levels of quitting amongst the workforces. Real quit rates were averaging between $80 \%$ and $120 \%$ per annum at BPO1, BPO2 and BPO4. Interestingly, BPO3, which had the smallest proportion of its workforce in voice-based call-center work $(20 \%)$, also reported the lowest voluntary attrition levels of 35\%. This operation, which rejected the call-center label as a description of its core business, employed $80 \%$ of its workforce in data processing/analysis work. Voice-based call-center work was 
taken on only if it built upon the core business of working with data. Such work was defined as requiring higher business entry and exit costs owing to the fact that it is more skilled (i.e. takes more time to become proficient in) (Interview BPO3, Associate vice-president HR). These claims accord well with the findings of our analysis where a poor match between supplied skills and required skills results in quitting.

Retention at the other three organizations, which were primarily call-center operations, was a more intractable issue. At $\mathrm{BPO} 2$ half of the $100 \%$ annual turnover occurs within the first 90 days of employment. At this center we were regaled with colorful examples that were indicative of the magnitude of the problem. These anecdotes included recounting the story of a motivational program that presented red roses of appreciation to female employees who turned up at their designated taxi pickup spots for the journey into work and of new recruits who were present at first day complementary breakfasts, but had left the employ of the company by noon (Interview BPO2, Chief people officer).

HR managers at BPO1 were cognizant of the fact that call-center work had a negative image in the community and that re-branding such work as a 'serious career' option was a major challenge. Horizontal job movement across different processes and clients was held out as one possibility to address the problem of job monotony and skill acquisition (Interview, BPO1, HR manager). Another variant of multi-skilling that was alluded to at this company was the creation of work teams that had responsibility for servicing multiple clients and processes on an ongoing basis (Interview, BPO1, Operations manager). Unfortunately, however, vertical mobility from ITeS work into more highly skilled IT work is not something that is countenanced as the required skill sets are simply too dissimilar for most ITeS workers to bridge.

Some companies, such as BPO3, now house a career management services section as part of their HR departments. This rubric not only includes standard functions such as performance appraisal and job evaluation but also includes within its mandate leadership development and the organization of internal job postings, which are now a standard practice at the company. Once again, though, career mobility between the ITeS and the more highly skilled IT arms of the company is at best an occasional occurrence usually involving managerial staff (Interview, BPO3, Associate vicepresident HR). This pattern largely mirrors the situation at BPO4. This company has introduced a program called 'Wings Within' that considers transfers between the ITeS and IT divisions. At the time of our interviews approximately 75 individuals had made use of this opportunity, but this is out of a workforce 12500 . Potential managerial talent is also identified through this company's Employee Advocate Group, which is run by the Talent Engagement and Development team. Participation in this team which is open to all process associates with one year's experience is intended to facilitate career enrichment for CSRs who have an aptitude for people management issues.

\section{Discussion}

These examples of concrete HR initiatives that are directed at the attrition problem are indicative of the demanding test that Indian BPO sets for the HR function. In this 
case, two out of the three factors that our analysis has identified as being most important in the retention/attrition conundrum lie beyond the immediate remit of HR. The state of the labor market is simply an external given. At the time of our study employers were finding it difficult to find enough employable graduates to keep up with industry growth. It is also questionable as to how much real influence HR can have over job design and the creation of a better skill/job mix. At the hiring end, it is generally not possible to employ individuals with less than tertiary education, owing to the language requirements of call-center-based service work and the distribution of English fluency among the workforce. At the same time work flows and key performance indicators are largely established by the principals who hire the services of the BPO providers. Upper most in their calculations are costs and efficiencies. Managing people in order to obtain desired results is precisely the activity that is being outsourced. The dichotomy of highly educated young people doing mainly semi-skilled work is part of the current reality of BPO. However, with the Indian BPO industry going up the value chain from low value, routine transactional tasks to high value, analytical and knowledge intensive tasks, there may be a window of opportunity for large, well-established employers to offer jobs that may more closely match employee skill sets and aspirations.

As for the third factor, the rationale and logic of outsourcing also places limits upon using bonus payments as a sole means of retaining workers. Competition for employable workers combined with the expectations of foreign principals that BPO costs will decline over the course of a service contract can lead to a cost/revenue squeeze, a complaint that was voiced in some of our interviews. With respect to job design, the labor process and remuneration systems, the BPO model places real constraints upon the options that are available for retaining workers. Meanwhile the nature of India's labor markets places other strictures on the type of workers who are hired in the first place.

This paper makes two major contributions to the current literature on HRM in Indian offshored call centers/BPO. It explicitly takes into account the external labor market conditions in analyzing employee retention and it empirically tests the effects of specific HR practices that are said to positively influence retention. Taken together, it presents a holistic picture and an integrated analysis of HR service delivery and outcomes in a fast changing global service business environment.

Currently, the HR function is constrained by its preoccupation with operational issues leaving little room to focus on longer term strategic matters and in particular job designs that align with the capabilities of the workforce. Our findings also reveal that while strategic HR initiatives by themselves may theoretically be strong enough to reverse the tide of employee attrition, the probabilities for adoption are limited as witnessed by the modest initiatives displayed by the case study firms.

For multinational companies and third-party vendors operating in Indian ITeS/ BPO, our study has several practical implications. Overall, satisfaction with the various aspects of HR examined in this study can at best be characterized as average (see the standardized mean scores in Table 1), while external labor market opportunities for this cohort of Indian BPO workers can be described as exceptionally good. Given the BPO work force profile and employee responses to our questions about their work, a picture begins to emerge of a significant gap between what social actors 
bring to the job in terms of skills and expectations and what the jobs offer regarding intrinsic work satisfaction. The unique features of the workforce may render this discrepancy more severe than that which has been experienced in western call centers. If we consider that the call-center labor process mainly requires semi-skilled qualifications then there is certainly a case to be made for a job/skill mismatch in Indian BPO.

There is wide diversity in the nature and types of call centers while offshore BPO adds to this diversity and complexity. Our study was confined to four large ITeS/BPO third-party providers and did not cover either the captive call centers of foreign transnationals or global third-party providers, where employee turnover is believed to be lower. Ideally, future research on Indian BPOs will compare indigenous providers with captives and foreign MNC outsource providers. Further, there are significant quantitative and qualitative differences in the nature of work performed in the various types of BPO activities, such as inbound, outbound, Internet-based chat, and knowledge-intensive professional services, which need to be considered in future studies. This article has only considered voice-based call-center work, but BPO is clearly more than that.

Finally, our research has some poignant theoretical implications. The relationship between globalization and HR has mainly been seen in a linear fashion, with HR 'best practices' expanding outwards from the West to the rest of the world. More attention is now needed to examine the effects of globalization, the new business models that accompany it and the local contexts on the practice of HR. The relationship between work designs, strategic HR practices and employee retention is moderated by external labor market conditions, changing business models, emerging technologies and employee aspirations. Our case study of Indian BPO providers exemplifies the changing dynamics of employment relationships and the challenges it poses to HR.

\section{Notes}

1. While our survey contains a bank of six questions pertaining to call monitoring, the inclusion of more items reduces the reliability of a monitoring index to a less than acceptable level.

2. Once again the addition of other relevant items to this index reduced its reliability to an unacceptable level. This may have been caused by the negative wording in which several questions were posed; e.g. "There tends to be an "us" and "them" relationship between employees and managers at this organization.'

3. HR as a discipline developed in the context of comparatively high levels of unemployment in a post-Keynesian policy environment.

\section{Appendix: Index items}

Work load manageability $(\alpha=0.775)$

1. The work targets that I am set are reasonable.

2. Management's expectations of work loads at this call centre are reasonable.

3. It is difficult for me to consistently meet my key performance indicators (reverse coded). 
4. I have sufficient time to read e-mails from my team leaders and managers.

5. I have an adequate number of breaks over the course of my working day.

6. I have an adequate amount of time between calls to compose myself.

7. I take as much time as is required to complete a call.

8. For me personally I feel the pace of work here is reasonable.

9. I have to work very fast to deal with the call volumes that we receive (reverse coded).

10. This call centre requires more employees given the general levels of call demand (reverse coded).

11. I have an adequate amount of time to meet the expectations of the caller.

Job skill $(\alpha=0.756)$

1. I have a great deal of responsibility to carry in my job.

2. This job makes full use of my education and experience.

3. I am satisfied with the opportunities that this job gives me to make use of my skills.

4. My work has a lot of variety in it.

5. There are opportunities for me to advance myself in this call centre.

6. I have a lot of discretion in responding to customers' questions.

7. I feel that my conversations with customers are too closely scripted (reverse coded)

8. Management treats me like a professional in this job.

9. We are encouraged to come up with new and better ways to do our job.

Training $(\alpha=0.736)$

1. The trainer(s) at this company do a good job.

2. The split between classroom and on-the-job training was about right.

3. The initial training that I received at this company was adequate for me to meet the expectations of my job.

4. The language training I have received at this company is adequate for dealing with our overseas customers.

5. The inter-cultural training I have received at this company is adequate for dealing with our overseas customers.

6. The pace at which material was covered in my initial training was too fast (reverse coded).

7. I feel that I should have received more training than I did before I went onto the phones (reverse coded).

8. I am given adequate training when new products and services are introduced.

9. I receive adequate training on new processes (e.g. software or new ways of doing things) in my job.

10. I can access additional training if I don't think I am adequately responding to customer questions.

11. I am expected to learn new things too quickly in this job (reverse coded). 
Work teams $(\alpha=0.752)$

1. If I am absent from work, I become concerned about the effects this will have on other members of my team.

2. The other members of my team are an important source of social support for me in the workplace.

3. My team leader tries hard to make this a good work environment.

4. I can always take a work related problem to my team leader for consultation.

5. Team meetings give me an opportunity to have real input into the way things are run at this company.

Monitoring $(\alpha=0.724)$

1. I receive useful feedback about the results of my monitored calls.

2. I am satisfied with the way in which call monitoring is used in this centre.

Workplace socialization practices $(\alpha=0.826)$

1. I usually participate in the organised social activities of the call centre.

2. I enjoy taking part in such social events as games and theme days at the centre.

3. The games and social events that are held at the call centre are an important aspect of the job for me.

4. I wish we had more organised social events, like theme days at this centre.

5. The performance competitions that management organise at the centre make working here more enjoyable.

6. I wish we had more performance competitions at this call centre.

Employee relations (ER) climate $(\alpha=0.749)$

1. Employees can trust this organization to do what's right by them.

2. This organization recognises and rewards employee loyalty.

\section{References}

Alvesson M (2004) Knowledge Work and Knowledge Intensive Firms. Oxford: Oxford University Press.

Applebaum E, Bailey T, Berg P and Kalleberg A (2000) Manufacturing Advantage. Ithaca, NY: Cornell University ILR Press.

Arthur J (1994) Effects of human resource systems on manufacturing performance and turnover. Academy of Management Journal 37(3): 670-687.

Arzbacher S, Holtrewe U and Kerst C (2002) Call centres: Constructing flexibility. In: Holtgrewe U, Kerst C and Shire K (eds) Reorganizing Service Work: Call Centres in Germany and Britain. Aldershot, UK: Ashgate, 19-41.

Bain P, Watson A, Mulvey G, Taylor P and Gall G (2002) Taylorism, targets and the pursuit of quantity and quality by call centre management. New Technology, Work and Employment 17(3): 170-185. 
Bain P and Taylor P (2000) Entrapped by the 'electronic panopticon'? Worker resistance in the call centre. New Technology, Work and Employment 15(1): 2-18.

Baldry C, Bain P and Taylor P (1998) Bright satanic Offices: Intensification, control and team taylorism. In: Thompson $\mathrm{P}$ and Warhurst $\mathrm{C}$ (eds) Workplaces of the Future. Houndmills, UK: Palgrave Macmillan, 163-183.

Batt R (1999) Work organization, technology and performance in customer service and sales. Industrial and Labor Relations Review 52(4): 539-564.

Batt R (2000) Strategic segmentation in front line services: Matching customers, employees and human resource management systems. International Journal of Human Resource Management 11: 540-561.

Batt R (2002) Managing customer services: human resource practices, quit rates and sales growth. Academy of Management Journal 45: 587-597.

Batt R and Moynihan L (2002) The viability of alternate call centre production models. Human Resource Management Journal 12(4): 14-34.

Batt R, Doellgast V and Kwon H (2006) Service management and employment systems in US and Indian call centres. In: Collins S and Brainard L (eds) Offshoring White-Collar Work. Washington DC: Brookings Institute, 335-372.

Bhatnagar J (2007) Talent management strategy of employee engagement in Indian ITES employees: key to retention. Employee Relations 29(6): 640-663.

Bristow G, Munday M and Gripaios P (2000) Call centre growth and location: Corporate strategy and the spatial division of labour. Environment and Planning 32(3): 519-538.

Budhwar P, Malhotra N and Singh V (2009) Work processes and emerging problems in Indian call centres. In: Thite M and Russell R (eds) The Next Available Operator: Managing Human Resources in Indian Business Process Outsourcing Industry. New Delhi: Sage, 59-82.

Budhwar P, Luthar HK and Bhatnagar J (2006a) The dynamics of HRM systems in Indian BPO firms. Journal of Labor Research 27(3): 339-360.

Budhwar P, Varma A, Singh V and Dhar R (2006b) HRM systems of Indian call centres: An exploratory study. International Journal of Human Resource Management 17(5): 881-897.

Cappelli P (1993) Are skill requirements rising? Evidence from production and clerical jobs. Industrial and Labour Relations Review 46(3): 515-530.

Clement W and Myles J (1994) Relations of Ruling. Montreal: McGill-Queen's University Press.

Combs J, Liu Y, Hall A and Ketchen D (2006) How much do high-performance work practices matter? A meta-analysis of their effects on organizational performance. Personnel Psychology 59: 501-528.

Das G (2002) India Unbound: From Independence to the Global Information Age. New Delhi: Penguin.

D'Cruz P and Noronha E (2006) Being professional: Organizational control in Indian call centres. Social Science Computer Review 24(3): 342-361.

Ellis V and Taylor P (2006) 'You don't know what you've got till it's gone': Recontextualising the origins, development and impact of the call centre. New Technology, Work and Employment 21(2): 107-122.

Fernie S and Metcalf D (1998) (Not) Hanging on the Telephone: Payment Systems in the New Sweatshops. London: Centre of Economic Performance, London School of Economics.

Frenkel S, Korczynski M, Shire K and Tam M (1999) On the Front Line: Organization of Work in the Information Economy. Ithaca, NY: Cornell University IRL Press.

Friedman T (2005) The World is Flat: A Brief History of the Twenty-first Century. New York: Farrar, Straus and Giroux.

Godard J and Delaney J (2000) Reflections on the 'high performance' paradigm's implications for industrial relations as a field. Industrial and Labor Relations Review 53(3): 482-502. 
Holman D, Batt R and Holtgrewe U (2007) The Global Call Centre Report: International Perspectives on Management and Employment. Report of the Global Call Centre Network (US format). http://www.ilr.cornell.edu/globalcallcenter/upload/GCC-Intl-Rept-US-Version.pdf (accessed 2 Jan. 2008).

Houlihan M (2002) Tensions and variations in call centre management strategies. Human Resource Management Journal 12(4): 67-85.

Huselid MA (1995) The impact of human resource management practices on turnover, productivity, and corporate financial performance. Academy of Management Journal 38(3): 635-672.

Hutchinson S, Purcell J and Kinnie N (2000) Evolving high commitment management and the experience of the RAC call centre. Human Resource Management Journal 10(1): 63-78.

Kinnie N, Hutchinson S and Purcell J (2000a) 'Fun and surveillance': The paradox of high commitment management in call centres. International Journal of Human Resource Management 11(5): 967-985.

Kinnie N, Purcell J and Hutchinson S (2000b) Managing the employment relationship in telephone call centres. In: Purcell K (ed.) Changing Boundaries in Employment. Bristol: Bristol Academic Press, 133-159.

KPMG (2004) Strengthening the human resource foundation of the Indian IT-enabled services industry. Report by KPMG in association with NASSCOM under the aegis of the Department of IT, Ministry of Information Technology and Communications, Government of India.

Lankshear G, Cook P, Mason D, Coates A and Button G (2001) Call centre employees' responses to electronic monitoring: Some research findings. Work, Employment and Society 15(3): 595-605.

Livingstone D (1999) The Education-Jobs Gap. Toronto, ON: Garamond Press.

Macduffie J (1995) Human resource bundles and manufacturing performance: Flexible production systems in the world auto industry. Industrial Relations and Labor Review 48(2): 197-221.

NASSCOM (2006a) Indian ITES-BPO Industry - Factsheet. New Delhi: NASSCOM.

NASSCOM (2006b) NASSCOM Announces Third Party ITES-BPO Companies Rankings for FY 05-06. New Delhi: NASSCOM.

NASSCOM (2008) Indian IT-BPO Industry Factsheet. New Delhi: NASSCOM.

Noronha E and D'Cruz P (2009) Employee Identity in Indian Call Centres: The Notion of Professionalism. New Delhi: Sage.

Pfeffer J (1998) Seven practices of successful organisations. California Management Review 40(2): 96-124.

Raman R, Budhwar P and Balasubramanian G (2007) People management issues in Indian KPOs. Employee Relations 29(6): 696-710.

Richardson R and Belt V (2001) Saved by the bell? Call centres and economic development in less favoured regions. Economic and Industrial Democracy 22(1): 67-98.

Richardson R, Belt V and Marshall N (2000) Talking calls to Newcastle: The regional implications of the growth in call centres. Regional Studies 34(4): 357-369.

Rose M (1994) Job satisfaction, job skills and personal skills. In: Penn R, Rose M and Rubery J (eds) Skill and Occupational Change. Oxford: Oxford University Press, 244-280.

Russell B (2002) The talk shop and shop talk: Employment and work in a call centre. Journal of Industrial Relations 44(4): 467-490.

Russell B (2006) Skill and info-service work in Australian call centres. In: Burgess J and Connell J (eds) Developments in the Call Centre Industry. London: Routledge, 92-116.

Russell B (2008) Call centres: A decade of research. International Journal of Management Reviews 10(3): 195-219.

Russell B and Thite M (2008) The next division of labour: Work skills in Australian and Indian call centres. Work, Employment \& Society 22(4): 615-634. 
Russell B (2009) Smiling Down the Line: Info-Service Work in the Global Economy. Toronto, ON: University of Toronto Press.

Shah V and Bandi R (2003) Capability development in knowledge intensive IT enabled services. European Journal of Work and Organizational Psychology 12(4): 418-427.

Sheshabalaya A (2005) Rising Elephant. New Delhi: Macmillan.

Sify (2006) India Inc gave heftiest pay hikes in Asia. http://headlines.sify.com/news/ fullstory.php?id=14136242.

Spenner K (1983) Deciphering prometheus: Temporal change in the skill level of work. American Sociological Review 48(6): 824-837.

Srivastava S and Theodore N (2006) Offshoring call centres: The view from the Wall Street. In: Burgess $\mathbf{J}$ and Connell $\mathbf{J}$ (eds) Developments in the Call Centre Industry. Abingdon, OX: Routledge, 19-35.

Sturdy A (2000) Training in service: Importing and imparting customer service culture as an interactive process. International Journal of Human Resource Management 11(6): 1082-1103.

Taylor P and Bain P (2006) Work organisation and employee relations in Indian call centres. In: Burgess $\mathrm{J}$ and Connell $\mathrm{J}$ (eds) Developments in the Call Centre Industry. Abingdon, OX: Routledge, 36-57.

Taylor P and Bain P (2005) 'India calling to the far away towns': The call centre labour process and globalisation. Work, Employment and Society 19(2): 261-282.

Taylor P and Bain P (1999) 'An assembly line in the head': Work and employee relations in the call centre. Industrial Relations Journal 30(2): 101-117.

Thite $\mathrm{M}$ and Russell B (2007) India and business process outsourcing. In: Burgess $\mathbf{J}$ and Connell J (eds) Globalisation and Work in Asia. Oxford: Chandos Publishing.

van den Broek D (2002) Monitoring and surveillance in call centres: Some responses from Australian workers. Labour and Industry 12(3): 43-58.

van den Broek D, Callaghan G and Thompson P (2004) Teams without teamwork: Explaining the call centre paradox. Economic and Industrial Democracy 25(2): 197-218.

Wallace C (2009) An overview of the Indian contact centre industry. In: Thite M and Russell R (eds) The Next Available Operator: Managing Human Resources in Indian Business Process Outsourcing Industry. New Delhi: Sage, 13-32.

Mohan Thite is senior lecturer at Griffith Business School, Griffith University, Brisbane, Australia. He has over 25 years of experience as human resources professional, both in industry and academia. He is a Fellow of the Australian Human Resource Institute. His research interests include strategic HRM in the knowledge economy, HRM in the Asia Pacific, HRM in multinational corporations from emerging economies and HRM in Indian IT/BPO. His publications include the book Managing People in the New Economy (Sage India), edited books on managing human resources in Indian BPO industry and human resource information systems, and articles in international journals.

Bob Russell is associate professor at Griffith Business School, Griffith University, Brisbane, Australia. He is the author of books on industrial relations in Canada, and work transformation in the mining industry. Currently he is conducting research on call centres, e-health, information work and globalisation. This material has appeared in Australian and international journals. Bob's latest book Smiling Down the Line: Info-service Work in the Global Economy was published in 2009. 